\title{
Talking about talk to talk about difference
}

Un populu mittitulu a catina

spugghiatulu

attupatici a vucca

è ancora libiru

livatici u travagghiu

u passaportu

a tavola unni mancia

u lettu unni dormi,

è ancora riccu.

un populu diventa poviru e servu quanno ci arrobanu la lingua addutata di patri:

è persa pi sempri.

diventa poviru e servu

quannu i parole nun figghianu parole

e si manciano tra d'iddi
You can put a people in chains

remove their clothing

stop up their mouths

they are still free.

take away their jobs

their passports

the table where they eat

the bed where they sleep

they are still rich.

a people become poor and servile

when their language is stolen

something received from their

forefathers

is lost forever.

they become poor and servile

when words don't birth words

and just consume each other

Extract from 'Lingua e dialettu' ('Language and dialect') (1970)

by Sicilian poet Ignazio Buttitta, translated into English

from Sicilian and Italian (translations by the author)

$I^{\mathrm{s}}$

FIRST CAME across Ignazio Buttitta, whose poem 'Language and dialect' (1970) is reproduced in part above, whilst I was thinking about the hierarchical weight given to different languages amongst the people I was speaking with in Napoli. Buttitta was a Sicilian poet and socialist, writing in the turbulent interwar and postwar period, who used his work to support popular struggle against fascism and the mafias. He helped to revive the Cantastorie tradition in Sicily by writing 
songs with a social and political content for itinerant storytellers to perform in villages across the countryside (Monelli 2014). He also chose to communicate his art exclusively in the Sicilian language. 'Language and dialect' speaks of language loss as a radical disempowerment of the people. Buttitta is referring to the inferior status ascribed to Sicilian, and other languages spoken on the Italian peninsula, in the wake of Italian Unification, when the spoken language of ordinary people came to be of pivotal interest to the political project of unification. The poem describes how the devaluing and impoverishment of spoken local languages, through state education and mass media, which promoted a written national norm, has caused significant damage to southern Italian identity, agency and self-esteem. At the same time, given Buttitta's contribution to popular struggle, the poem can be read as a call to arms both to protect the local cultural and linguistic heritage and to allow it to continue evolving. This speaks to a notion of identity that is fluid, open and able to negotiate the relations of domination.

From the beginning of my research I noticed that there was a hyperawareness, amongst born-and-raised Neapolitans as well as more recent arrivals to the city, of how multiple communicative forms shaped their existences in ways that were both painful and joyful. They talked frequently about talk in relationship to wider questions of cultural difference, belonging and entitlement, and this fascination was filtered through the power-laden history of language recounted in Buttitta's poem. I came to think of this talking about talk as a particular kind of speech genre (Bakhtin 1986) that attended both to the fraught regional history of language and to the multiaccentual, ambiguous and provisional dialogic processes at stake in a contemporary Napoli that was multilingual and multicultural as a result of migration into the city from across the so-called Global South. Beyond simply telling us a particular story about southern Italy, this spoke to wider questions about the relationship between language and hierarchies of difference where 'language attitudes' were actually about dominant and subordinated people and cultures, and became a form of racism (Smitherman 1977: 191-197). This notion of language attitudes allowed me to connect the personal feelings people expressed about the act of talking in Napoli to the power-laden, ambivalent and pragmatic verbal dynamics of transcultural interaction in the city's street markets.

In the street markets where I did ethnographic research, talk about talk shaped communication in a number of ways: as a way of reflecting melancholically on what Napoli was, as well as what it was in the process of becoming; as a practical necessity whereby migrants and Neapolitans had learnt from each 
other through socialisation and working together; and as a means of making claims about belonging or expressing ambivalent forms of solidarity. The different language attitudes that emerged through people talking about talking directly addressed the complex linguistic dynamics that arose within a local context where anti-immigration politics rubbed alongside the pervasive notion that Neapolitans were themselves subordinated and so more open to cultural difference. The patterns of culture and communication related to Napoli's history as a port meant that it was almost always possible to talk, even under unequal, improvisational and ambiguous conditions. But there were also moments where the linguistic dexterity people described themselves as relying on failed, and where transcultural interaction between migrants and Neapolitans working in street markets fell apart. People talked about being able to talk, but also sometimes claimed they were not able to talk to, or be understood by, each other. Thus, this chapter explores how people talked about talk, but also considers the problem of communication breakdown, seeking to define the threshold where interactions reached the edge of sociality and failed.

\section{Talking about talk as a Neapolitan melancholia}

It was lunchtime at Via Bologna, early on in my fieldwork. I was sitting on a plastic carton outside Riccardo's shop eating a sandwich that Sohna had made for me on her mobile food stall. Sohna and her husband, Serigne, were there keeping me company, along with Riccardo, who was standing at the entrance of his shop taking some air. The sandwich filling was a thick Senegalese chicken stew, or soupe as they would call it, with lettuce leaves and a slathering of mustard-mayonnaise and hot sauce. I was at the quiet end of the market but I could hear the vendors' calls from the more busy stalls further down the road, along with the faint notes of Egyptian music from a CD stall and the revving of mopeds and cars going round Piazza Garibaldi. A young Roma girl of about 5 or 6 approached me with her hand stretched out, asking for something without me being able quite to catch the words. I knew her, as she spent most days on the street playing within safe distance of older relatives. She had decided she wanted to befriend me. I offered her my unopened soft drink but Serigne shouted at her to 'leave people alone when they're eating!' She looked chastened and walked quickly away. Serigne turned to me and told me 'they are all the same', and Riccardo opined, 'It's in their DNA to ask for stuff.' There was an awkward pause. I didn't know Riccardo very well yet so I told him a bit more about the research I was doing. I explained that I was interested in how Neapolitans and migrants got on with each other and how 
Napoli had changed as a result of migration. He told me that I should be looking at particular neighbourhoods in Napoli in order to get an understanding of the different 'realities' at play in the city. To illustrate this, he told me how in the Quartieri Spagnoli people still had Spanish words in the Neapolitan they spoke. ${ }^{1}$ For example, they said 'è salita' instead of 'è scesa' to say 'she's gone out'. ${ }^{2}$ For Riccardo these cultural 'realities' were part of an older emotional legacy, related to domination and sea trade, that pushed in, uninvited, to forcefully interrogate the contemporary urban situation. And above all, for him, these 'realities' were linguistic. The way people talked showed their cultural and biological lineage. He might say it was an audible manifestation of their 'DNA'. In a conversation about contemporary migratory dynamics, he instead referred to historic cultural differences within the city's settled community, highlighting its reputation as an exoticised and precarious place. He talked about talking as a way of talking melancholically and nostalgically about Neapolitan history.

Talk about talk in Napoli allowed many people to deal with feelings of loss about Napoli as it used to be, as well as to express the anxieties they felt about their social, economic and political futures. The collision between a protective and subordinated local identity and the fraught politics of globalised migration often inspired a retreat into more exclusionary and exclusive notions of belonging. But at the same time it could generate a sense of horizontal solidarity that crossed racialised boundaries and explained itself through the trope of Neapolitan friendliness and simplicity, generating a problematic kinship with other 'Others'. Often these melancholic reflections about belonging and Neapolitan identity revolved around concerns about what was being transmitted to the younger generation. One day a man called Augusto dropped by Gennaro's stall to say hi to him. This conversation ensued when he found me there:

\section{Augusto: Sprechen Sie Deutsch?}

Me: No, zero Deutsch I'm afraid.

Gennaro: German is the language of angry people! It's an angry language!

Augusto: Yeah! When I hear all that 'ich' ... 'mach' ... It's angry.

Me: So you think a language shows the personality of the people who speak it? In that case what are English people like?

Gennaro: Well ... a bit nicer at least! OK, look, for me this is how it is: French is a language I really like, then Spanish and then Italian. Then I would like to speak English because they speak it all over the world. But you know it really gets me ... when a woman speaks Spanish ... how can I put this? It's a language you speak with your tongue between your teeth - 
Me: You mean it's sexy?

Gennaro: Ehum ... well [embarrassed] ... And then French is musical -

Augusto: And Neapolitan is like African - you sing it ... Us lot, you know -

Neapolitans, Africans, Arabs ... we sing our words, like ei! Or uagliò! [ways of calling people's attention] It's like it's sung ... you know: sung!

Gennaro: [referring to Augusto] He's like me, a Neapolitan. So he's naturally friendly.

Augusto: Yeah Neapolitan people are all like that, like they're clowns, but people appreciate that. Deep down Neapolitan people are just friendly dumbasses.

Me: What do you mean?

Augusto: It means you let people have one over on you.

Gennaro: No, look. We are streetwise people but we are a people that resign ourselves. Something bad happens and it's all: 'ok let's see' and 'what can you do?', 'things'll get better', 'let's wait and see' ... And other people don't do that! We just let the big things go even if in our daily lives we are clever and tricky - because when someone says 'Oh you're Neapolitan are you?!' they mean 'You're a thief!', 'cause all of us Neapolitans are thieves - but really we just have our eyes wide open, you get what I'm saying?

Augusto: Anyway. The real Neapolitan doesn't even exist anymore.

Me: What do you mean? They've disappeared?

Augusto: It's all because there's this accumulation of ... the more the black race comes over here ... and it's like that in nearly all the other cities.

Me: Well things change for good as well as bad.

Augusto: I guess. The real Milanese doesn't exist anymore either ...

Me: Yeah, well I guess that's because Milan is full of Neapolitans!

Gennaro: But you know Napoli was so lovely because ... we used to have all these metaphors ... for example, look, I'll give you an example. My older daughter when she wants to get her own way she has her mum not knowing whether she's coming or going and I tend to be stricter. Then, sometimes, mum gets strict about something and she comes to me asking for whatever it is she wants. I get fed up and tell her 'you're like Magdalen's boat!' $\mathrm{Oh}$ - how can I explain that one to you? - you know the thing is even she doesn't understand - it's hard to explain but it's like a boat that bobs one way and then the other... it's like saying you're not steady ... you understand? We say Magdalen's boat ... you go wherever you feel like! 
Augusto: You go in whatever direction the wind blows fastest, do you get the metaphor?

Gennaro: Exactly. And, you know, my daughter doesn't understand any of these things.

Me: Does your daughter speak Neapolitan?

Gennaro: She can speak it, but not like me.

Me: So what is your daughter to you? Is she more Italian or more Neapolitan?

Gennaro: So, look: I've got a strong Neapolitan accent, like him as well [points to Augusto]. If we want to speak Italian we can but when my daughter speaks Italian you can't even hear an accent.

Me: How come?

Gennaro: Because she's going to school ... and anyway - we've always tried to speak Italian because I can't assume that she's going to be able to stay here in Napoli or if she's going to have to go to the north or some other place to work.

Me: Yeah, that's why my mum never let me speak dialect ...

Gennaro: But you know if she wants to speak dialect, she can ... And when I have to speak Italian sometimes I get a bit stuck because I have to do a quick bit of translation.

Initially, both Gennaro and Augusto argued that the language you speak in constitutes your identity in ways that shift between fixed and fluid notions of belonging. Gennaro drew upon a number of familiar, stereotypical and exotic notions about what national languages express about culture and identity, but then agreed with Augusto when he likened Neapolitan to the sound of West African languages and Arabic. Neapolitan and African languages were described as being similar because they are both 'sung', suggesting intriguing commonalities between Napoli and places further south. This speaks to a number of interconnected accounts of Napoli as a friendly city, as hybridised or as belonging to the racialised edge of Europe.

Then the jokey and crude masculine banter about the stereotypical cultural characteristics of different national languages segued into a more melancholic territory of anxiety, loss and regret. Starting with the question of Napoli in terms of its difficult political, economic and social climate, the conversation digressed smoothly and inexorably towards the issue of language extinction and cultural erosion. This change of tone was precipitated by Augusto's comment about 'the more the black race comes over here', again highlighting the power of blaming migration for anxieties about economic security and cultural identity. Augusto 
claimed there were no real Neapolitans anymore because of the cultural dilution that had resulted from migration, despite the fact that he had made a fraternal link to these migrants by comparing the way Africans and Neapolitans spoke. Thus, the two men stopped short of raising the possibility of any real solidarity with the migrants in their midst, while ambivalently recognising that they sounded like them. I pointed out that southern Italians were, and continued to be, migrants in northern Italy and Europe - as a way of reminding them of the historic discrimination internal migrants had faced in Italy (Signorelli 2006: 36), which they themselves were now reproducing with regard to migrants in Napoli. But this fell on deaf ears. Instead, contact with cultural difference evoked a melancholic aggression leading both men to speak of the pain of their own subordination and ethnic humiliation when stereotyped as sly thieves. They ambivalently recognised the Other's alterity in the alterity they themselves had been subjected to, but refused to draw the links together into some kind of productive or emancipatory politics in the present. Whilst attending anti-racist events in the city I often heard Italian activists allude to the history of Italian emigration in order to call for kinship and solidarity. But this 'politics of speech', as Judith Butler noted (Bell and Butler 1999: 165), often failed, was only partially successful or was unpredictable. Here, it yielded a melancholic display of victimhood that did not allow the two men to work through the complex webs that connected their disenfranchisement to that of more unfortunate people around them.

Gennaro went on to transfer these melancholic feelings into the realm of the familial and, again, found it necessary to talk about the act of talking in order to explain this to me. However, this time he talked about not being understood, or not being able to talk, as a way of explaining these feelings of loss. His dramatic phrase 'we used to have all these metaphors' referred to the richness and depth of Neapolitan language and culture that had not been fully transmitted to his children's generation. In order to give an example, he described telling his daughter 'si 'na varca 'e Matalena' ('you're like Magdalen's boat'), and his sadness at her uncomprehending response to a common phrase from his own childhood. Popular religious legend has it that Mary Magdalen crossed the Mediterranean from the Middle East to Europe in a boat with no oars. The metaphor Gennaro described using with his daughter expressed the idea of life as changeable and unpredictable. When pressed, Gennaro admitted that he and his wife did not encourage their daughters to speak Neapolitan because of the likelihood of their having to leave the city to find work, and the historical prejudices faced by Neapolitans who migrated internally and externally. As with my own upbringing, strategies to protect against such prejudice have 
often focused on the question of language and accent, but there was a sad price to pay for this. It was interesting that Gennaro used a metaphor he felt to be rooted in the Neapolitan landscape that, in fact, recalled fluidity and migratory movement. It evoked memories of mass emigration from the Italian peninsula as well as - for me - conjuring up images of the small boats arriving at that moment on Mediterranean shores. For Gennaro and Augusto, nostalgia around eroding forms of culture and communication did not allow them to connect productively to this present emergency.

\section{Talk about talking English}

These feelings around loss, movement and departure, related to speaking Neapolitan or Italian, were also connected to preoccupations about speaking English. Renato Carosone's famous song 'Tu vuò fa ll'americano' described a Neapolitan man who effected the American leisure activities of the 1950s by dancing to rock and roll, drinking whisky and soda, and even speaking English. It was a satire about Americanisation in Italy in the postwar years:

Tu vuò fa' ll'americano

Comme te po' capi' chi te vo' bbene

si tu lle parle miezo americano?

quanno se fa ll'ammore sott' 'a luna

comme te vene 'ncapa 'e di' 'I love you'?
You're a wannabe American!

How can the people who love you understand you

If you speak half American?

And when we make love under the moon

How can you think to say: 'I love you'?

As well as pointing towards the cultural influence that America has wielded over the world throughout the twnetieth and twenty-first centuries, the song spoke to particular histories of philo-Americanism in the city. It evoked the Allied presence there from 1943, which in some ways continued from the 1950s in the form of the NATO base. It also recalled the tens of thousands of returnee Italian emigrants who came back to Italy - many from North America - from the 1930s. As Carosone's song showed, emigrant returnees and American soldiers, with their fashionable clothing, money and foreign speech, seemed almost irresistibly glamorous to those Italians who had stayed behind. 'L'americano' became a common nickname given to Italians of a certain age who had travelled abroad and 
so were considered worldly. But this glamour was tied up with the sadness of loss and departure, which was the legacy of both war and migration. Italian people continued to emigrate in their millions well into the twenty-first century and, in fact, the sampling of Carosone's song in the international house hit We No Speak Americano by Yolanda Be Cool and DCUP (2010) demonstrated the on-going salience of these emotions about migration and needing to speak English.

In the street markets of my research, historic tensions and internalised inferiority complexes around speaking English reappeared in mutated form because English had become a sort of lingua franca between Neapolitans and new migrants arriving in the city (Dawes 2016). This raised issues around being able to talk with prospective customers, especially in Poggioreale market, where English was the principal language of communication between vendors and their West African customers, who came to Napoli specifically to bulk-buy leather goods. It also highlighted uncomfortably the ways in which speaking English was connected to the workings of power and appropriation. In so doing it made uncomfortable connections between Neapolitan otherness and those whose encounters with English in colonial West Africa and South Asia had been much more violent and destructive. The following statement was made by Ade, a Nigerian man who was visiting Poggioreale market:

Ade: Like you were asking me, I think one of the problems I had when I came in - because I came in from Milan - was the language problem. Because I only speak English so I found it difficult to communicate. And some people, if you talk to them and they don't know what you're saying, they get angry or don't want to talk to you again. So I find it difficult to communicate and then get to the people and then know them. I walked on my own, just all by myself, just doing nothing because I can't speak with anybody. I can't talk so to find out how the people behave is difficult for me. I can't really speak ... and they can't understand me either. So it's a big problem for me!

Me: Are you planning to come to Italy again?

Ade: Oh yes. Maybe next year...

Me: And will you learn some Italian for that?

Ade: In marketing they should learn English because most of who they deal with are foreigners so to be able to interact and communicate ... If you speak English and the customer speaks English they will find it easier to be with you. There is more from Africa coming to buy ... so it's time for them to start learning some English so they can reach out and sell more. 
Here, Poggioreale market figured as a microcosm of global capitalism, where speaking English was the default and supposedly neutral marker of economic progress. I asked the Neapolitan vendors at Poggioreale market whether it was stressful for them to use English when conducting business. Some of them took the situation of English-speaking African customers in their stride. When I first met Ciro and Titti of the Eddy Pell stall they exclaimed that it was great I spoke English as I could help them negotiate with all their English-speaking customers. Then they jokingly told me that I wouldn't be much good, as I myself would need to learn what they called the 'dialects' of English that their customers really spoke. They told me that when clients asked how much a bag cost, they knew to pronounce the 'thirty' of 'thirty-four euros' as / t3:t1:/ not /ez:tt:/, as I said it. Titti told me she and her husband had never been scared to throw themselves into communication in other languages. She put this down to the fact that they had both finished school, unlike the majority of the vendors with stalls around them. However, this sense of playfulness and resourcefulness did not extend to all the vendors I spoke to. This is how Peppe, of Peppe's Bags, responded to my question about haggling in English:

Peppe: Well you know ...

Me: Is it the language thing or their methods, or both?

Peppe: No it's because they're much more ... for me it's about something else. Me: Well I guess you're used to it by now.

Peppe: You should see what they do! They buy thirty bags and then another one of them will want the bags and then it's all 'No I got them! Anyway ... then you put them to one side and tot up the bill and then it's all 'wait a minute!' And then they pick one bag up and remove another and in the end they don't want any of them and they've convinced someone else to buy them. Then, sometimes we take the sold bags straight to the hotel. When we get there, out of thirty to fifty bags - all made of leather that you have sold and brought all the way there - all of a sudden they try to return thirty of them. You know, you've bought fifty bags and not let anyone else buy them then you have them brought to the hotel where you can get comfortable and have another look at them. I won't have that! You've already spent two hours looking at them in the market! I'm telling you ... But then there's other people that are... good customers ... they come and buy thirty bags straight up. [brief pause] You know the language thing is so important for us though.

Me: The fact that you need it to work? 
Peppe: No, I mean the fact of having to communicate with them ... We get angry because ... well ... my son knows a thing or two but not much really ... you get me? What can you do?

Me: I understand. Everyone who comes to buy speaks English or French.

Peppe: Yeah ... but you know: there's also quite a few of them that know a bit of Italian. Quite a few ... I just wish I was twenty years younger so I could go off and learn English. You know it's always been like this ... that English has been spoken here ... we knew we should get studying English. But in our day our parents, well, we just didn't go to school. My son also didn't want to do any type of studying and he's raising his own son this way as well, because my grandson doesn't want to study. It's always a cause of big arguments ...

For Peppe, talk about talking English reawakened latent memories of emigration and foreign influence in Napoli. The kinds of mourning this inspired became the lens through which transcultural relations were experienced in the contemporary moment. Peppe veered between blaming his African customers for not doing business respectfully and honestly, drawing on racist notions of black unruliness, and then blaming himself for not being sufficiently educated and disciplined to have learnt English properly at school. He recognised the stress of participation in the global economy as an old legacy, showing an awareness of how contemporary issues of poverty and precariousness are connected to historical processes of disenfranchisement and the uneven legacy that modernity has inscribed on different parts of the world.

It was true that Peppe and his son, Alessandro, did not find negotiations with foreign customers so easy. They employed English-speaking help on their stall but often lost their tempers when those employees didn't respond quickly enough or correctly understand their Italian instructions. Often I would see both Alessandro and his dad shout 'When are you going to learn some Italian, eh?!' at their staff before repeating the same command in a louder and more menacing tone.

The linguistic dynamics between Neapolitan vendors, African and Eastern European employees and African customers at Poggioreale revealed the contingent and uneven ways in which power enmeshed them together in their everyday relationships with each other. The vendors at Poggioreale spoke English to their English-speaking customers because they had to, but not all of them communicated respectfully with their foreign staff. This was because people were positioned in different ways according to ambivalent and shifting hierarchies of wealth and status. Comic language could temporarily suspend those hierarchies and allow 
new horizontal conceptions of diversity to appear, as Titti and Ciro's joking comparison between Nigerian English and standard English showed. But humour, as has been shown elsewhere (Bakhtin 1984 [1965]; Passerini 1987), could often act as a portal to abusive and oppressive language, for example with Alessandro and Peppe and the way in which they wielded their linguistic frustrations against their foreign staff.

\section{Teaching and learning new languages}

Many of the street vendors I spoke with elsewhere in the city also emphasised the importance of learning how to talk in different languages for their everyday working relationships. Having latterly moved into the market at Via Bologna, Gennaro had opened his market stall in Piazza Garibaldi in 1993 and had witnessed all the changes that had occurred there since that time. Early on in the research I asked him whether - as I had read elsewhere in work about migration in Napoli (Dines 2002) - it was true that Neapolitan street vendors had learnt bits of Ukrainian and Arabic in order to talk with non-Italian-speaking vendors and customers. He confirmed that, when migrants started arriving in large numbers in the late 1980s and early 1990s, he and the other Italians learnt some basic business words in their languages to be able to trade with them. Eventually, the new arrivals who settled in the city started to learn Italian and Neapolitan, and now these were the languages that were predominantly being spoken in markets around Piazza Garibaldi. At Porta Capuana market many of the Italian stall owners had also hired foreigners who had all learnt to conduct trade in Neapolitan or Italian. For example, over the years they had learned to use Neapolitan slang for money, such as: $n$ 'a triglia rossa (a red mullet) $=10,000$ lira, o'caravaggio $=100,000$ lira, o'babà $=€ 50 .{ }^{4} \mathrm{He}$ felt that this evidence of extensive linguistic transmission and hybridisation over many years proved that Neapolitans were not racist. It was interesting that he connected my question about language to issues around migration and racism, because I had not asked him whether he thought Neapolitans were racist or not.

Gennaro's defence continued in the next story he told me. He explained that he had a knack for learning languages because he was able to understand all the Africans at Via Bologna just from their gestures and tone of voice. This had helped him in a number of tricky situations, including one that he described as an episode of 'reverse racism'. Most market traders with established pitches didn't carry all their goods back and forth but stored them close to their place of work. He told me about an occasion when he had wanted 
to rent a storage depot together with a Malian friend, Moussa, and another Malian man he didn't know. This Malian man refused and had a fierce argument about it with Moussa in Bambara. Eventually Moussa explained that the man was not keen because there wasn't enough room. But Gennaro said that perhaps there was more to it and Moussa eventually admitted that the other Malian man didn't want to share a depot with Gennaro because he thought Neapolitans were dishonest and made problems for everyone. Despite being hurt by this, Gennaro stayed friends with Moussa and they went on to rent a space together with Comfort, a Nigerian woman with a stall at Via Bologna market. But even there they had problems. Initially the Nigerian lady who was renting the space out, on behalf of an Italian owner, had asked for $€ 300$, but she eventually asked for $€ 500$. 'In the end', he said to me, crossing his fingers together in a steeple, 'we're all linked to each other. It's just that sometimes things don't work out.'

So, for Gennaro, multiple language-crossing practices, and the pedagogic processes that facilitated them, were related to the pragmatic necessity of getting by in a cosmopolitan and globalised reality where both migrants and Neapolitans earned money side by side through some sort of retail activity. This connected Napoli to other global port cities that have become sites of a 'practical cosmopolitanism born of an acceptance of - and indifference to - difference'. In Napoli, a pragmatic approach to living with difference involved the development of particular forms of 'cultural dexterity' and learning how to negotiate and barter in many different languages (Trotter 2008a: 684-685, b: 87). Gennaro described the way in which this worked, through a combination of active learning and intuitive attempts at communication. The practical cosmopolitanism he outlined activated the notion of Napoli as an open and welcoming port city, hence his claim that multilingual interaction across transcultural boundaries was indicative of an innate Neapolitan anti-racism. Without wishing to discount his distress at being stereotyped as dishonest because of being Neapolitan, the equivalence that he argued this created between his situation and those of his migrant colleagues was problematic. It elided the issue that, for example, factors such as race, nationality and legal status had bequeathed very different life outcomes to him and Moussa, his Malian colleague. The significance he gave to his story drew upon a local form of Neapolitan postracialism - predicated on the idea of Neapolitans as friendly and welcoming because of their own historic experiences of oppression and prejudice - that sought to deny racism as a local problem and thus reduced all social struggle to a question of economic inequality between the poor and the rich. 
Pedagogic linguistic exchanges were central to many of the ambivalent and contingent transcultural mediations I recorded in my field notes. For example, this was the perspective of Salvatore, a doorman along the Rettifilo who had an uneasy friendship with a Senegalese street vendor called Ibra:

Salvatore: Ibra and the others [Senegalese street traders] can read Italian all right! Sometimes they ask me Italian words so they can learn more. For example, they point to a moped and ask how you say that in Italian. All the street traders down this road that I know are good people. And, you know, there's good and bad everywhere. I ask them words in their own language as well, to make friends and to tease them you know ... Like, I might ask them, 'How do you say ugly?', and then I call them ugly! [I smile] Good! You've understood the game. Here's another one: manga dem means 'I'm going home, bye.' I say it when they leave but sometimes I also say it when they arrive in the morning to tell them jokingly to go away. There was this other guy who spoke good English. Often tourists would ask us all directions in English and I would tell this guy what to say, and also give some advice about precautions to take with your stuff around the train station. But I would do this so it wasn't obvious it was me feeding him the instructions because then the tourists might think I was threatening them, 'cause of what people think about Neapolitans.

In accordance with the Janus-faced nature of joking and laughter, the episodes of teasing in each other's languages that I saw created the opportunity for both a transcultural conviviality and a racialised power slapdown. Humorous disparagement, particularly directed at migrant men by Neapolitan men, often served to reinstate hegemonic anti-immigration stereotypes. But poor Neapolitan men were themselves victims of gendered and racialised discrimination - as evidenced by Salvatore's fear, expressed above, that people might think he was a thief if he were to try and help them. The ambivalent nature of multilingual sharing and tormenting between Neapolitan and migrant men in my fieldwork was connected to the unstable racialised position that Neapolitan men occupied. Their aggression against non-white men was a way in which they sought to make up for their own economic, political and cultural disempowerment.

The laughter produced by these uneven and unequal pedagogic practices occasionally allowed for moments of male bonding - such as that in the photograph of Ibra and Giovanni, who owned the grocery store behind the spot where Ibra generally set up his market stall (see Figure 11). Ibra, Giovanni and I agreed 


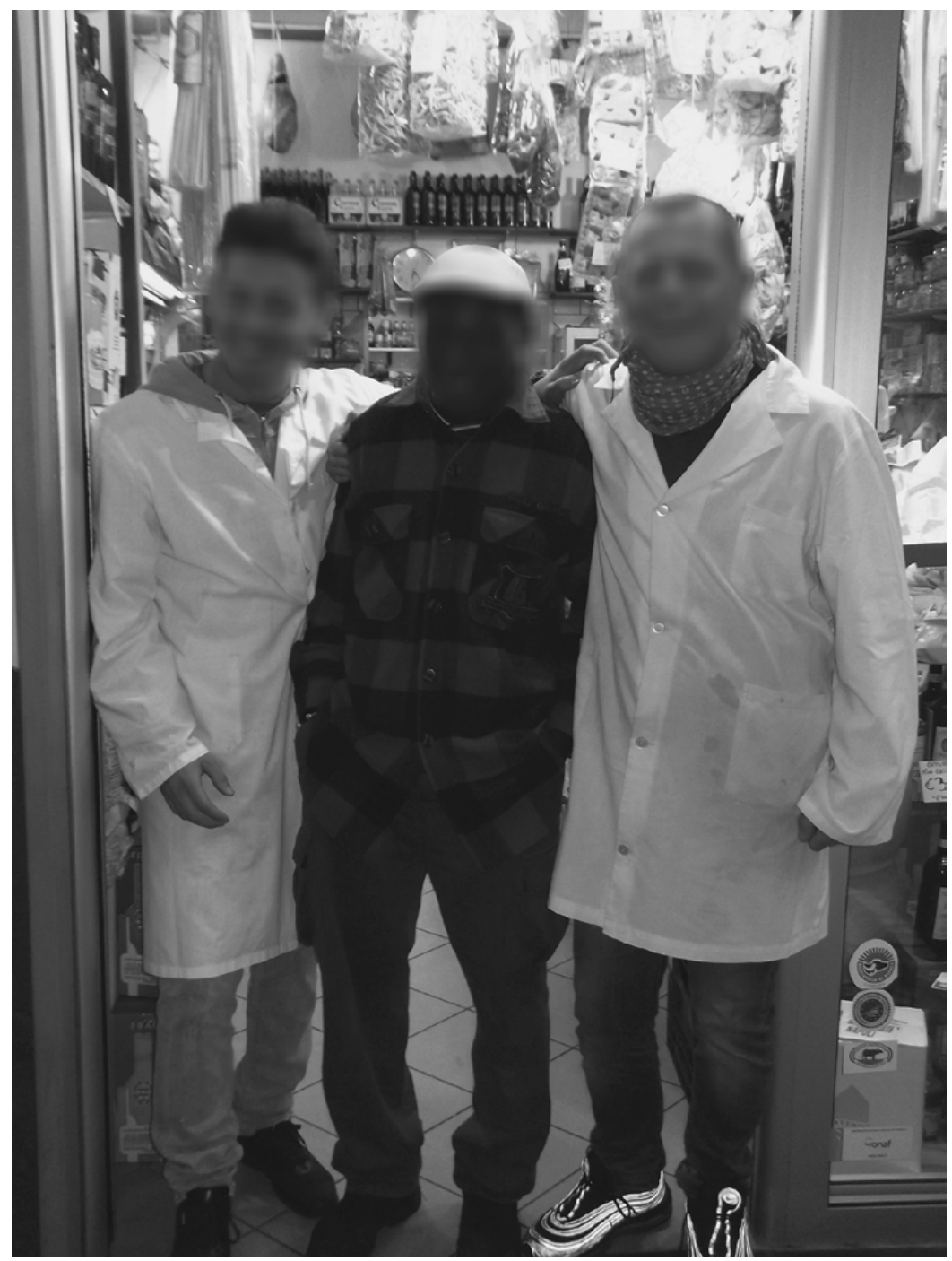

11 Ibra, Giovanni and colleague in front of Giovanni's shop

it showed what good friends they were. On looking at the digital image, Giovanni gently joked to Ibra that the photo hadn't come out very well because they were both pretty ugly. Salvatore, who was also present, agreed that they were all gorgou niaw ('ugly man' in Wolof), and all three men cracked up laughing. Then Salvatore said, 'but Ibra, where are you? I can only see two people and a black stain in the middle!' Salvatore used his learned Wolof as a weapon against Ibra in his malicious joking. He appealed to the innocent and open nature of these 
pedagogic interactions whilst, at the same time, using them as part of a vigorous and sharp takedown that drew on racist stereotypes that black people don't show up in photographs because of their skin tone.

\section{Knowing how to talk}

For migrants usch as Moussa, a street vendor who had come from Mali, learning to speak the local language and - critically - knowing when to deploy particular linguistic skills had been key to gaining 'street cred' and defending themselves from racist harassment:

Me: So how do you think Italians treat foreigners in Napoli at the moment?

Moussa: Well because of the crisis, at the moment there are a few problems. Racism is much better though - well, better anyway ...

Me: I understand. So then years ago, when you arrived in Italy, what did they used to say to you?

Moussa: Listen ... OK, let's be honest here ... every now and then they would call me 'black', 'African' -

Me: Anything else?

Moussa: They would say 'negro', 'slave'. They would call you 'Kunta', you know, in Neapolitan so you couldn't understand ... you know Kunta: that American slave? ${ }^{5}$ So now I understand, well, I can defend myself. But you know it's a totally different story now. Where we are now things are definitely a little better.

Humorous linguistic prowess was central to self-defence and the negotiation of ambivalent solidarities in many of the moments of transcultural encounter I observed in public spaces across the city. The following episode took place on the eve of the day of Epiphany on the train from Napoli to Sorrento. I was sitting in a crowded compartment of people who had mainly come to Napoli for the day to visit the festive market stalls. In Italy this had always been a religious holiday of equal importance to Christmas Day. It began with a middle-aged Polish man (who had Italianised his name to Piero) who started up a conversation with a group of young Italian teenage men, sitting opposite him, about the merits of drinking a little vodka in order to get up and go to work first thing on a winter morning. As was typical of train conversations in the Italian south, progressively more people got involved in the conversation as things got more entertaining: 
Teenager 1: Is Poland in the EU?

Piero: Poland has been in Europe for seven years! Schengen for three! Do you know what Schengen is?

Teenager 1: Erm, no ... [trails off] So what is it anyway?

Piero: Ha, I can see you don't understand! You obviously haven't done school, have you? I have studied a lot. It's to do with people committing crimes and police being able to chase them across borders. You all think Polish and Romanian people are shit don't you?

Teenager: Not at all! [His friends all nod and hold their hands palm-side up in a gesture of peace.]

Piero: [returning to a conversation point that had clearly started before I had got on the train] You know, another thing vodka's good for is curing a cold. You need to put loads of pepper-

Teenager 2: How many spoons?

Piero: Loads!' It's gotta taste like shit! This is what we drink on New Year as well: two bottles of bubbly and ten of vodka!

Laughter rattled round the train compartment. The teenagers got up to shake Piero's hand before leaving. At this point another young Italian man, Alessandro, started up a conversation with Piero who, it turned out, he vaguely knew.

Alessandro: You know I work in Eastern Europe, across Croatia, in Zagreb.

Piero: Oh yeah? I've worked in Croatia too. What other places do you know?

[They listed a number of small towns they had been to.]

Alessandro: So how's your friend, what's he called, Alfonso?

Piero: Oh-Alfons! Yeah-he's good. You and me do know each other don't we? I'm that 'Polish bastard'!

Alessandro: No - it's not like that. We don't see it like that.

Piero: [to the woman sitting to his right] Madam I should apologise for swearing. [She smiled, looking a bit uncomfortable. Piero then turned to the man sitting next to me.] Are you Polish?

Man: No - I'm Albanian.

Alessandro: What language do they speak in Albania?

Man: Mainly Albanian and Italian.

Piero: In Poland we only speak Polish, but we had to learn Russian at school. What's the point of that? Nowadays what you really need is English and French.

[Everyone nodded and murmured in agreement.] 
Piero: [to the Albanian man] How long have you been here?

Man: Only four months.

Piero: What?! You speak such good Italian!

Alessandro: Yeah - that's amazing!

Man: I know. But you know I spoke Italian before 'cause we speak it in Albania. I also speak Yugoslav [sic] and Greek. ${ }^{6}$

Alessandro: You know what job you could get here? [He perhaps meant a cultural mediator.]

Man: Oh I already have a job. I'm a tattoo artist. I had my own shop in Greece and I want to open one up here but I need to get to know people first.

At this point the three men started comparing tattoos and another Italian man joined in the conversation, as he wanted to pay for a tattoo for his girlfriend. The Albanian man introduced himself as Besi and his friend sitting next to him as Ahmed from Morocco, and they all started swapping numbers. Everyone in the train compartment, including myself, was watching avidly and people were leaning in from the corridor to get a good view of the discussion. People laughed and reacted to what was being said. In the middle of this my sister called me to find out when to pick me up from the station and I had to make a critical decision about what language to answer the phone in, finally opting for a mix of both. The atmosphere in the train compartment thickened palpably. Piero got off at Pompei, kissing Alessandro, Ahmed and Besi goodbye on each cheek and promising to catch up again soon. The four remaining men moved to sit all together. The Italian man, Giuseppe, who wanted to buy a tattoo for his girlfriend started talking:

Giuseppe: You know - I'm an artist, a painter. I've been looking for any kind of work for seven months, but nothing!

Besi: There's work here! You could be a labourer, you know? Just to get by. I don't manage just on tattoos. By day I'm a carpenter.

Giuseppe: [crossing his arms angrily across his chest] Oh yeah? Where is this work?

Besi: Well, we all find work ... but you know there's this economic crisis going on so ...

Giuseppe: How did you come to Italy?

Besi: We got our visas in the latest round of immigration amnesties, didn't we? [He turned to Ahmed, who nodded in agreement.]

Ahmed: We decided to stay in Napoli 'cause, you know, people are nicer down here. They're not as mean as they are up north. 
Alessandro: It's true. They're such cold people up there.

Besi: No - it's also because Neapolitans also go out to work like us.

Alessandro: Yeah - that's true as well.

Besi: What do you all think about immigrants?

Alessandro: [spreading his arms wide] For me it doesn't matter where you're from ... it just matters that you're a friend to me.

Their discussion turned to wages in the south and the low cost of living. The train had emptied a lot by now and the four men had been enjoying their chat so much that Besi, Ahmed and Giuseppe had missed their stop. They got off at Castellammare to get a return train and, as they exited, Ahmed turned to me to say goodbye as well.

\section{Ahmed: Bye English! [I smiled]}

Alessandro: [to me] So where are you getting off?

Me: Vico Equense.

Alessandro: Me too! Are you from there?

It turned out Alessandro and I were from the same village and he went to school with my eldest cousin. We said goodbye at the train station and promised to say hello if we saw each other again.

This episode was a testament to the collective and dialogic familiar speech via which people work through ideas of difference, belonging and positionality in public spaces in Napoli. Here, talk about talk - which incorporated discussion about how many languages people spoke, what languages were useful, what were key phrases and words to learn and how well people spoke a language allowed people who had never met (or didn't know each other very well) to have an open and fun discussion about fraught issues such as immigration and unemployment. The conversation about speaking as a hierarchical and political practice connected the fates of the migrant and Neapolitan men in the carriage to the kinds of precariousness and instability that they were seeking to survive and overcome. This spoke both to the kinds of interconnected work activities that they got involved with in order to make ends meet in the south of Italy, and to the reasons why people had to move away from home to get work. Ahmed suggested, to general agreement, that they understood each other better because Neapolitans 'go out to work', by which he meant that many had historically been forced to emigrate in order to find dignified employment. Their joking, swearing and laughter, which included everyone in the train carriage whether they 
contributed to the discussion or not, created a temporary suspension in normal hierarchies that allowed for transcultural tensions to be lifted and for difficult things to be discussed. Together, a transverse and non-essentialist vision of cultural difference was imagined, where they helped each other to stay strong and imagine a better future. However, their talk, although part of a conscious public performance, did not allow the equal participation of the women in the carriage, as Piero's apology for swearing illustrated. The men's banter defused tensions and established a playful and competitive masculine bonhomie that illustrated the importance of mobile and fluid performances of locally hegemonic masculinities in Napoli (Connell and Messerschmidt 2005). However, on this occasion at least, these performances could not fully incorporate women into the dynamic of their sociality.

The acts of switching between different languages were also central to the alternative cultural configurations being imagined. This revealed the ambivalent, shifting and temporary conceptualisations of social difference between the men involved in the discussion and involved complicated decision-making processes. Piero's choice to speak in a Neapolitanised Italian for the whole conversation was a statement about his own right to belong in Napoli, even though he said right at the beginning that he had always worked mainly in Rome and northern Italy. Besi did the same thing when he responded that he knew he spoke good Italian by saying it in dialect (' $o$ ' saccio' instead of 'lo so'), although he spoke Italian for the rest of the conversation. The particular history of domination in Napoli often revolved painfully round the question of Neapolitan, and so decisions to use or not use dialect, or to switch between different languages and registers, were never neutral for either locals or newcomers. To quote Moussa again, 'I can speak Italian and Neapolitan. Lots of my Malian friends can't do that. And I know when to speak Neapolitan and when to speak Italian.' Moussa's statement about knowing what language to speak, and when, connected talk to the ways in which masculine street cred and respect were mobilised in Napoli. The Italian men in the train carriage episode above all spoke in a regional Italian, except for Giuseppe, who slipped into Neapolitan when he got annoyed with Besi. In so doing he reasserted cultural dominance over Besi through the performance of a guappo masculinity that showed he was ready to protect his honour and dignity, with aggression if necessary. At the same time, he expressed brotherhood and solidarity in their shared creative spirit and horizontal struggle to find work, showing the ambivalent nature of playful masculine performances when cut through with hierarchical notions of race and ethnicity. The other young Italian men chose to speak Italian, as they had been taught that this was the way 
to be polite and respectable since their early years of school. They would also have felt that speaking Italian made it easier for outsiders to understand them. They did not realise that migrants in Napoli usually learned Neapolitan, or a Neapolitanised Italian, because that was the language they came into contact in through the kinds of work they did, and in everyday street encounters.

Linguistic aptitude was important in other multilingual professional contexts I entered into through my contacts in anti-racism and migrant rights. In Italy, professional cultural mediators occupied an important role as linguistic and cultural intermediaries among migrant groups or between individuals and State institutions. They were qualified to work in places such as schools, hospitals and migrant advice bureaus, with the aim of interpreting and carefully negotiating on behalf of people who couldn't speak the official language of the country they were in. Many of the activist friends I made whilst seeking access for this project in Napoli were professional cultural mediators, including Omar. The way in which they worked in different spaces of the city, from the street market to City Hall, taught me a lot about the values placed on language for negotiating unequal power dynamics and demonstrating support and solidarity across transcultural boundaries.

One afternoon in January, after Via Bologna market had closed for the day, I went with Omar to meet his colleague Luisa, an Italian cultural mediator at a migrant advice bureau around the back of the train station. After we had been there for a while, a Ukrainian woman came into the bureau and, seeing me, immediately mistook me for a conational and started talking in Ukrainian. We all laughed and Omar blustered 'not again - she's English!', as it was not the first time it had happened since he had met me. The woman laughed wryly as if recognising that she had been the victim of a practical joke. She then explained that she had come on behalf of a friend who had been put in prison. She wanted us to call the friend's lawyer, as she believed they would take someone who spoke good Italian more seriously. Omar and Luisa gave her the advice she needed, and after she left, this provoked a discussion about whether Italians or migrants made better cultural mediators for other migrants. The question of language was central to this. Omar argued that a good mediator did not have to speak grammatically perfect Italian in order to be successful. Instead, he said, they needed to understand different cultures and how domestic and international laws worked. He hated having his Italian corrected and wished people would just listen to what he was saying. He also believed that often people corrected him as a way to mobilise power against him. In a way this assertion was reinforced by the woman who had come to the bureau - to whom we all spoke Italian without 
any problem - when she asked for a native Italian speaker to contact the lawyer on her behalf.

Multiple ways of referring to people talking were used in this situation to position the different social actors, including myself, within and against a hierarchy of belonging and entitlement in Napoli. The ability someone might have to understand Neapolitan culture because of their position as an insider or outsider, as well as the ability to recognise where people might be from, were related to the uneven workings of power via the ideological superiority ascribed to the figure of the native speaker (Rampton 2003). This figure was seen to have the best chance of a good outcome in their interactions with the spectre of the lawyer and the other institutional bodies that migrants and their mediators regularly had to interact with. This was revelatory of the ways in which hierarchical 'language attitudes' were used to subordinate and silence vulnerable people. However, the communal laughter we all shared also created a temporary break in the hierarchies we ourselves were discussing, allowing for a transverse and non-reductive coexistence with difference, or a Relation, to emerge. Our ability to speak, mediate and argue on our own or others' behalf showed the ways in which transcultural solidarity could be used to speak back to hegemony.

\section{Not talking at all}

However, there were times when these ambiguous processes of linguistic pedagogy and mediation between Neapolitans and migrants broke down and failed. This meant that people claimed they couldn't understand what was being said to them, even if they were actually communicating effectively. It also meant that people became paranoid about whether or not people were lying to them or dissimulating about how much they could speak or understand. These processes where people described 'not talking at all' were indicative of how far talk about talking could go when it came to the daily negotiation of difference, belonging and entitlement in multicultural Napoli. The notion of not being able to talk revealed the ideological force represented by racial hierarchies and nationhood, manifesting as a sort of violent monolingual nationalism that rejected the possibilities opened up by a daily multilingual Relation.

For example, early in my research I was taken by Luisa, the mother of one of my gatekeepers, to Duchesca Market. This market ran through the back streets behind the statue of Garibaldi in Piazza Garibaldi and was famous for selling contraband and stolen items. The vendors were predominantly Neapolitan and West African and the atmosphere in the market was tense and circumspect when 
I went there. Luisa wanted to introduce me to her nephew, Gianni, who sold labelled jumpers. We approached his stall and they greeted each other affectionately as they hadn't seen each other in a while. She told him I was doing a project about markets in Napoli and asked him how the Italians and the foreigners got on with each other in the Duchesca. 'No, we don't get on at all', he responded, his mouth turning down at the corners. But at this moment a black man appeared behind him and asked Luisa, 'Are you his mum?' 'No, I'm the aunty', she responded, 'so you know Gianni?' The man smiled broadly and told her, 'This is my brother!' Gianni nodded in acknowledgement of his presence, but did not smile back.

Luisa encouraged me to tell the man about my work. As I was speaking he became more and more withdrawn: 'Sorry, I don't understand', he told me. He pointed to another African man with a stall opposite Gianni's and told me to explain to him. I started speaking, trying both Italian and French, but again the man told me he couldn't understand me, and passed me on. The third man I spoke to introduced himself as Abdou and smiled encouragingly at me. He got out his work visa for me, ostensibly to show me how to spell his name but really, I suspect, to prove he had a right to remain in the country. Abdou told me I was welcome to come back and spend time on his stall. We swapped numbers and Luisa and I went back to Gianni's stall to say goodbye. Gianni also said I could come and do fieldwork with him, but he thought I should sit with him and not with the African vendors. I never ended up doing further fieldwork at Duchesca Market. It was subjected to a series of police raids and I decided I didn't feel safe spending extended periods of time there.

Here the denials of understanding on the part of the three West African vendors I spoke to were revelatory of the threat I represented as an unknown interloper into a market where illegal and semilegal activities were happening that it might be better not to subject to excessive scrutiny. Negotiating this was a key part of gaining access and managing risk in the field for me. Throughout my fieldwork, I noticed that claiming not to understand was a key strategy used by migrants, particularly when authority figures were exercising control over them. In this case I was making them anxious, as they weren't sure who I was or where I came from, so it was better for them to avoid responding directly to my explanations and questions. This silence could be interpreted as a form of resistance, as it interrupted the flow of the dominant discourse and forced intersubjective interactions to become opaque and unclear. As Glissant argued, in postcolonial contexts opacity has historically provided protection from the surveillance of the oppressor when the face-to-face of daily Relation became 
impossible (Britton 1999: 19-25; Glissant 1981: 14-19, 1997: 114, 190). At the same time, as Scott noted, this tactic of 'linguistic veiling' has also helped to fuel racist stereotypes of non-white people as sub-intelligent (Scott 1990: 32-36).

Gianni's refusal to acknowledge and speak to the African man who approached us as we were talking was a different sort of not understanding; it was an ideological refusal to recognise him as a fully fledged fellow human. His evident dislike of working alongside black street vendors was compounded by my presence, a young white women and therefore eliciting white males fears about racial intimacy and miscegenation. The African man's use of kinship titles was a failed attempt to establish a convivial Relation, as 'ò fra', or 'my brother', is a common way of addressing male companions both in Napoli and across West Africa. Gianni refused to talk back to him and the potential for a moment of intersubjective Relation was rejected.

The mirror image of this problematic appeared elsewhere when I witnessed economic transactions where customers were totally convinced that the vendors couldn't understand them, even when evidence to the contrary was presented to them. This was particularly true in the case of Chinese street vendors, who were criticised for self-segregating and believed to be incapable of learning Italian. At Ku's stall, I noticed that most of the customers communicated with gestures, holding out their phone and pointing at the charger socket, or repeating the name of the item they were looking for over and over again, such as 'Padlock. Padlock.' Ku had been in Italy for six years at this point and I knew he could speak Italian, as that was the language we communicated in. But his customers didn't seem to think he could understand or respond to complex phrases. One African man approached the stall, looking for a USB stick. He picked up a multipack and put his fingers round one of the sticks, indicating he wanted only one from the pack: 'How much?' 'Three euros', said Ku. The man made a shocked face and held the pack up again: 'How many here? One, two, three, six [counting on his fingers]! How much all?' Ku responded resignedly that the whole pack cost 'seven euros'. 'So one euro!' Ku accepted to sell the USB stick for $€ 1$ and the man moved off. On one memorable occasion, a middle-aged Neapolitan man approached Ku's uncle's stall, holding out his mobile phone. He pointed to the charger socket:

Man: [pointing] Eh! Eh!

Ku's uncle: A phone charger?

Man: Eh! Eh! [noises to indicate agreement]

[Ku's uncle showed him the charger.] 
Man: How much?

Ku's uncle: Three euros.

Man: Eeeeeeei?! [He rubbed his thumb and forefingers together to indicate that the price was too high.]

[Ku's uncle shrugged and the man moved on.]

The Neapolitan customer was so convinced that Ku's uncle couldn't understand him that he failed to compute that the vendor's calm and sensible responses were spoken in perfect Italian. In fact, he turned himself into a parody of what he believed Ku's uncle to be: an incomprehensible and insensate foreigner who could only be communicated with in a limited way through the use of grunts and gestures. He believed that the alterity of Ku's uncle was too great to be overcome.

A bitter sense of classed and racialised victimhood also animated other interactions between Neapolitans and migrants, causing them to suspend their efforts at transcultural communication even at moments when the need to earn a livelihood was at stake. For example, on one occasion Modou, Omar and I were sitting outside the bar next to Modou's stall having a coffee when a Neapolitan street vendor approached us, asking if we would like to buy a lighter or a notepad and pencil for a few cents. We declined politely with a tilt of our heads and then studiously ignored him while he continued to stand there: 'I have a family', he informed us plaintively. We looked at the ground. 'Do you speak Italian?', he asked us, changing tack. We didn't respond. His gaze settled on me, the only white person and the only woman at the table: 'Do you speak Italian?' I capitulated and said that I did. 'No, No. I don't believe you', he said, 'you're Polish aren't you?' I raised my eyebrows at this and shrugged my shoulders. He also shrugged and walked away.

While it might have initially appeared that the street vendor wanted to know if we could speak Italian in order to facilitate communication and persuade us to buy from him, his reaction to my assertion that I could indeed speak Italian suggested that there was something rather different at stake in his question. The vendor asked us whether we could speak Italian as a way of calling us out as not Italian and therefore outsiders. It was a power slap-down inflicted because we refused to buy his wares and this made him angry. Mobile street-vending of such low-value goods as the man was selling was the most vulnerable form of street vending and indicated that his economic situation was particularly precarious. His mobilisation of these ideas about belonging, 'race' and national belonging - which he chose to deploy because of, and despite, his urgent 
economic situation - suggested that there were racist logics that sat outside the need for cosmopolitan cooperation and convivial codependence.

This was not the only time that fraught politics surrounding understanding and not understanding across transcultural boundaries led to racist exclusion and paranoia. On one occasion I was standing with Comfort at her stall at Via Bologna market when Omar showed up. Comfort started complaining about the troubles the market was experiencing until, all of a sudden, she received a call telling her that there had been an explosion in her home town in Nigeria. She rushed off to a nearby phone centre to call her family there, and there was a general upheaval and panic around us as other Nigerians in the market did the same. At the same moment, an approaching police patrol caused the Guinean street vendors at the top of Via Bologna to run away into the back streets of the Vasto neighbourhood. Omar and I started talking about the laws surrounding the production and sale of contraband. Then, two Senegalese vendors with stalls within the market approached Omar and started speaking to him angrily in Wolof. The argument got heated and I caught French words such as 'antiracisme' and 'Angleterre' coming from Omar. I suspected that they were arguing about my presence in the market. Everyone else who didn't speak Wolof, including Comfort returning from her phone call, looked on in confusion. A Neapolitan man asked Comfort what they were saying and she told him that she didn't understand. The man looked affronted and commented that it was 'not possible', with rancour in his voice, as if he believed she was deliberately keeping the information from him. After a few more minutes of discussion Omar seemed sufficiently to calm and reassure the two Senegalese vendors who returned to their stalls, still visibly fuming. Omar told me they had heard us having a discussion about contraband the previous day and were convinced I was a councillor spying on them from City Hall. He had to work hard to convince them of my true identity and good intentions.

Different racialised language attitudes were at work in the scene that played out next to Comfort's stall. The Neapolitan man who questioned her about the argument assumed she understood because he assumed that all the Africans at the market spoke the same language or were in some way all the same as each other. These ideas were contested amongst Neapolitans. Gennaro, who had a stall within the market, was well aware that there were different nationalities amongst the African vendors there, and was sensitive to the tensions of crosscultural communication that often arose. However, this other Neapolitan man's assumption of linguistic homogeneity had its roots in colonial constructions of a 'dark continent' without history or cultural diversity. Nestling alongside this was the common assumption that people talking in a language you didn't understand 
were automatically a threat to you. This was connected to a monolingual nationalism that equated the speaking of multiple languages, that were not the official national language, with betrayal and social breakdown.

Talk about talking, or not being able to talk, was a potent indicator of the way the past bled into present intersubjective relations in Napoli, revealing the ideological struggle inherent in the use of language. It contained the potential to transform melancholy into a more productive mourning, leading to pragmatic cosmopolitan collaboration, or even transcultural solidarity and resistance. At the same time, the coexistence of nationalistic, reductive and stereotypical ideas about language-speaking - such as the paranoid resentment of not being able to understand the Other - demonstrated the strength of language ideologies, and their obsessive link to power interests, boundary maintenance and group membership. All communication was multilingual, multiaccentual and strategic. The French-inflected Wolof of the angry Senegalese market vendors, as well as the Neapolitan-inflected Italian used by Comfort, Omar, the Neapolitan man and myself in the above scene, all attested to the ways in which we could use different semiotic resources, both within and without conventionally defined languages, in order to construct meaning together in dialogue. The linguistic choices we all made showed how community could be made or broken through 'semantic guerilla tactics' (Hewitt 1986: 205). In the following chapters I will move away from talking about talk to think about how people actually talked to each other as they sought to communicate across transcultural boundaries in Napoli's street markets.

\section{Notes}

1 The Quartieri Spagnoli was originally a garrison built during the sixteenth century to house the Spanish soldiers needed to quell Neapolitan revolts against the Bourbon rulers.

2 Actually they say 'è sagliut'. Riccardo automatically translated the Neapolitan into Italian as he could see I wasn't local.

3 In other words: how can you think to say I love you in English instead of saying 'ti amo' in your native language? Carosone and Salerno (1956), translation mine. Renato Carosone (1920-2000) was a Neapolitan singer-songwriter.

4 A babà is a typical and much-loved Neapolitan pastry, similar to a brioche and soaked in dessert rum.

5 Kunta Kinte is a character in the 1994 novel Roots by Alex Haley, which has been adapted twice into a hugely popular television series. Haley claimed that Kunta Kinte was one of his ancestors, a Gambian man who was enslaved and sent to America in the eighteenth century.

6 Serbo-Croatian is one of the spoken minority languages in Albania. This is probably what he mean by 'Yugoslav'. 